\title{
Implementasi Kebijakan Pemulihan Ekonomi Nasional (PEN) Melalui Program Bina Desa Mandiri Peduli Gambut di Kawasan Eks PLG Sejuta Hektar Provinsi Kalimantan Tengah
}

\author{
Fengky F. Adji ${ }^{1 *}$, Sosilawaty ${ }^{2)}$, Untung Darung ${ }^{1)}$, Nidya $^{3)}$, Kadek Malina Silva ${ }^{4)}$, Khairunnisa ${ }^{4)}$, \\ Fernandes $^{4}$ \\ 1) Jurusan Budidaya Pertanian, Fakultas Pertanian, Universitas Palangka Raya \\ 2) Jurusan Kehutanan, Fakultas Pertanian, Universitas Palangka Raya \\ 3) Lembaga Penelitian dan Pengabdian Masyarakat, Universitas Palangka Raya \\ 4) Fakultas Matematika dan Ilmu Pengetahuan Alam, Universitas Palangka Raya \\ *Penulis Korespondensi : fengky@agr.upr.ac.id
}

\begin{abstract}
Abstrak
Pandemi Covid-19 secara global menimbulkan banyak korban jiwa tercatat sejak pertama kali virus Covid-19 terjadi di Wuhan, China hingga saat ini 14 Desember 2020 jumlah kematian sebanyak 1.618.103 jiwa. Melihat kondisi ini maka dirasa menjadi sangat penting tindakan yang dilakukan pemerintah dalam melandaikan kurva (flatten the curve) dengan bebarapa kebijakan dan peraturan. Salah satunya yang dilakukan oleh pemerintah Indonesia, adalah dengan melaksanakan program PEN (Pemulihan Ekonomi Nasional), agar tidak menyebabkan dampak yang lebih buruk lagi dari penerapan physical distancing atau Pembatasan Sosial Berskala Besar (PSBB) terkait pemulihan ekonomi di masyarakat. Terlebih saat ini keberadaan Kawasan eks Proyek Lahan Gambut (PLG) sejuta hektar di Kalimantan Tengah menjadi perhatian penting terkait 3R (Rewetting, Revegetation, and Revitalization), yang dalam hal ini program PEN pada Kawasan eks PLG ini diprioritaskan dalam peningkatan ketahanan pangan. Berdasarkan hal di atas, Program ketahanan pangan yang saat ini dilaksanakan oleh beberapa kementerian, yang salah satunya adalah Kementerian Lingkungan Hidup dan Kehutanan oleh Direktorat Jenderal Pengendalian Pencemaran dan Kerusakan Lingkungan, yang dalam hal ini dikoordinasikan oleh Direktorat Pengendalian Kerusakan Gambut (PKG) bekerjasama dengan Fakultas Pertanian, Universitas Palangka Raya di eks PLG dilakukan salah satunya melalui pendekatan pemberdayaan masyarakat yang dinamakan Program Bina Desa Mandiri Peduli Gambut. Program ini adalah kerangka penyelaras untuk program-program pembangunan yang ada di pedesaan gambut, khususnya didalam dan sekitar areal restorasi gambut. Pendekatan yang digunakan adalah merajut kerjasama antar desa yang ada dalam satu bentang alam Kesatuan Hidrologis Gambut (KHG). Pembentukan kawasan pedesaan gambut menjadi pintu masuk bagi perencanaan pengelolaan gambut oleh desa-desa tersebut.
\end{abstract}

Kata Kunci: Pandemi Covid-19, Program PEN, Gambut, KHG, dan Kemandirian Masyarakat

\section{PENDAHULUAN}

Kejadian pandemi Covid-19 adalah kejadian extraordinary. Dampak signifikan terasa pada sisi kesehatan, sosio-ekonomi, hingga sektor keuangan. Perlu Langkah cepat untuk melandaikan kurva penyebaran Covid19 di Indonesia (flattening the curve). Caranya dengan upaya penanganan kesehatan dan physical distancing atau Pembatasan Sosial Berskala Besar (PSBB). Namun, dari upaya ini ada beberapa konsekuensi yang dihadapi, yaitu: sektor sosial (berhentinya aktivitas ekonomi yang menyerap tenaga kerja terutama sektor informal), sektor ekonomi (kinerja ekonomi menurun tajam karena konsumsi terganggu, investasi terhambat, ekspor-impor terganggu, dan perlambatan pertumbuhan berbagai sektor), sektor keuangan (sektor keuangan ikut bergejolak karena dampak penurunan kinerja sektor riil. Oleh karena itu pertumbuhan ekonomi yang turun tajam ini akan menimbulkan dampak sosial, antara lain: pertumbuhan ekonomi menurun akan menyebabkan peningkatan PHK dan pengangguran meningkat, bersamaan dengan itu masyarakat miskin akan semakin meningkat. Berdasarkan data dari Kementerian 
Keuangan RI (2020), bahwa proyeksi pertumbuhan ekonomi Indonesia tahun 2020 sebelum pandemi Covid-19 (APBN) sebesar $5.3 \%$, namun setelah terjadi pandemi Covid-19 diskenariokan menjadi (berat $2.3 \%$ dan sangat berat $-0.4 \%$ ). Kondisi ini juga akan berdampak terhadap peningkatan angka kemiskinan (skenario berat +1.89 juta orang, skenario sangat berat +4.86 juta orang), dan akan terjadi juga peningkatan angka pengangguran dengan skenario berat +2.92 juta orang dan skenario sangat berat +5.23 juta orang). Melihat kondisi ini pemerintah terus berupaya menjaga agar pertumbuhan dan dampak kesejahteraan tidak menuju scenario sangat berat, dilakukan salah satunya adalah melalui program Pemulihan Ekonomi Nasional (PEN). Program ini dirancang untuk memulihkan ekonomi Indonesia dengan melindungi masyarakat miskin dan rentan miskin serta mendukung dunia usaha agar tidak makin terpuruk.

Terlebih saat ini keberadaan Kawasan eks Proyek Lahan Gambut (PLG) sejuta hektar di Kalimantan Tengah menjadi perhatian penting terkait 3R (Rewetting, Revegetation, and Revitalization), yang dalam hal ini program PEN pada Kawasan eks PLG ini diprioritaskan dalam peningkatan ketahanan pangan. Dalam rangka mengamankan kesediaan pangan nasional serta mengantisipasi kelangkaan dan krisis pangan, Pemerintah Indonesia terus mengambil langkah strategis dan taktis untuk meningkatkan produktivitas tanaman pangan dalam rangka menjamin ketersedian stok pangan nasional sehingga ketahanan pangan nasional dapat tetap terjaga. Pemerintah melalui Kementerian Pertanian menyampaikan bahwa akan membuka sawah baru di Kalimantan Tengah di lahan eks-PLG (Pengembangan Lahan Gambut) melalui pengembangan lahan mineral, rawa dan lahan gambut yang potensial untuk pangan. Provinsi Kalimantan Tengah menjadi salah satu pilihan pengembangan sentra/lumbung pangan andalan nasional.
Ekosistem gambut merupakan salah satu ekosistem yang memiliki peran dan manfaat penting bagi kehidupan manusia, dimana saat ini telah dimanfaatkan untuk berbagai kegiatan pembangunan. Manfaat tersebut antara lain: pensuplai air dan pengendalia banjir, potensi wisata, mata pencaharian masyarakat lokal (pertanian, perkebunan, perikanan), stabilitas iklim, keanekaragaman hayati, serta untuk pendidikan dan penelitian. Selama 30 tahun lebih pengelolaan lahan gambut, kurang memperhatikan penerapan prinsip pemanfaatan berkelanjutan. Berdasarkan pengalaman dan permasalahan yang terjadi pada Proyek Pengembangan Lahan Gambut (PLG) di atas, maka diperlukan intervensi untuk meningkatkan daya dukung ekosistem gambut, khususnya melalui pemulihan fungsi ekosistem gambut, baik melalui restorasi maupun rehabilitasi vegetasi. Intervensi restorasi gambut melalui tata kelola air sangat diperlukan untuk menjaga stabilitas tata air di ekosistem gambut agar dapat mendukung ketersediaan air bagi pengembangan pertanian. Namun demikian keberhasilan dalam pengelolaan ekosistem gambut terlebih pada lokasi yang berdekatan dengan aktivitas masyarakat, peran masyarakat sangat diharapkan.

Berdasarkan hal di atas, Program ketahanan pangan yang saat ini dilaksanakan oleh beberapa kementerian, yang salah satunya adalah Kementerian Lingkungan Hidup dan Kehutanan (KLHK) oleh Direktorat Jenderal Pengendalian Pencemaran dan Kerusakan Lingkungan (PPKL), yang dalam hal ini dikoordinasikan oleh Direktorat Pengendalian Kerusakan Gambut (PKG) bekerjasama dengan Fakultas Pertanian, Universitas Palangka Raya (FP - UPR) di eks PLG dilakukan salah satunya melalui pendekatan pemberdayaan masyarakat yang dinamakan Program Bina Desa Mandiri Peduli Gambut. Program ini adalah kerangka penyelaras untuk program-program pembangunan yang ada di pedesaan gambut, khususnya didalam dan 
sekitar areal restorasi gambut. Pendekatan yang digunakan adalah merajut kerjasama antar desa yang ada dalam satu bentang alam Kesatuan Hidrologis Gambut (KHG). Pembentukan kawasan pedesaan gambut menjadi pintu masuk bagi perencanaan pengelolaan gambut oleh desa-desa tersebut. Program desa peduli gambut meliputi kegiatan fasilitasi pembentukan kawasan pedesaan, perencanaan tata ruang desa dan kawasan pedesaan, identifikasi dan resolusi konflik, pengakuan dan legalisasi hak dan akses, kelembagaan untuk pengelolaan hidrologi dan lahan, pemberdayaan ekonomi, penguatan pengetahuan lokal dan kesiapsiagaan masyarakat desa menghadapi bencana kebakaran gambut. Oleh karena itu program ketahanan pangan yang diwujudkan dalam program Bina Desa Mandiri Peduli Gambut ini tidak hanya tertuju kepada peningkatan produktivitas lahan gambut yang berorientasi kepada ketahanan pangan dan pelestarian ekosistem gambut, melainkan juga untuk mewujudkan kepedulian dan kemandirian masyarakat desa terkait perlindungan ekosistem gambut. Dalam hal ini, tentu saja selain sebagai konsep, juga merupakan metodologi atau pendekatan pemberdayaan dipandang menjadi pilihan strategis menuju ketahanan pangan berkelanjutan, bahkan menjadi input utama menuju pemulihan, pengendalian dan pengelolaan ekosistem gambut berkelanjutan.

Berdasarkan hal ini, maka program Bina Desa Mandiri Peduli Gambut yang dilakukan di Provinsi Kalimantan Tengah ini bertujuan: 1. Untuk mendapatkan gambaran awal dan potensi pengembangan peningkatan perekonomian masyarakat desa terkait Penguatan Ekonomi Nasional (PEN), serta kepedulian masyarakat dalam menjaga ekosistem gambut; 2. Melakukan sosialisasi kepada masyarakat akan program Bina Desa Mandiri Peduli Gambut; dan 3. Memberikan edukasi bagi masyarakat akan pentingnya lahan gambut sebagai kawasan penyangga dan penyimpan karbon (C).

\section{METODA PELAKSANAAN}

Adapun kegiatan Bina Desa Mandiri Peduli Gambut ini dilaksanakan selama 2 (dua) bulan, yaitu bulan November - Desember 2020 yang berlokasi pada 3 (tiga) kabupaten di Provinsi Kalimantan Tengah, yaitu: Kabupaten Kapuas, Kabupaten Pulang Pisau, dan Kabupaten Barito Selatan. Dalam hal ini dilaksanakan pada 18 (delapan belas) desa/kelurahan, yaitu: Kelurahan Panamas, Kecamatan Selat, Kabupaten Kapuas; Desa Lahei Mangkutub, Kecamatan Mantangai, Kabupaten Kapuas; Desa Tumbang Muroi, Kecamatan Mantangai, Kabupaten Kapuas; Desa Babai, Kecamatan Karau Kuala, Kabupaten Barito Selatan; Desa Tampulang, Kecamatan Jenamas, Kabupaten Barito Selatan; Desa Tabatan, Kecamatan Jenamas, Kabupaten Barito Selatan; Desa Penda Barania, Kecamatan Kahayan Tengah, Kabupaten Pulang Pisau; Desa Tanjung Sangalang, Kecamatan Kahayan Tengah, Kabupaten Pulang Pisau; Desa Pulau Kaladan, Kecamatan Mantangai, Kabupaten Kapuas; Desa Mahajandau, Kecamatan Dusun Hilir, Kabupaten Barito Selatan; Desa Mantangai Hilir, Kecamatan Mantangai, Kabupaten Kapuas; Desa Sei Ahas, Kecamatan Mantangai, Kabupaten Kapuas; Desa Kalumpang, Kecamatan Mantangai, Kabupaten Kapuas; Desa Mantangai Hulu, Kecamatan Mantangai, Kabupaten Kapuas; Desa Mantangai Tengah, Kecamatan Mantangai, Kabupaten Kapuas; Desa Katimpun, Kecamatan Mantangai, Kabupaten Kapuas; Desa Sei Jaya, Kecamatan Dusun Hilir, Kabupaten Barito Selatan; dan Desa Katunjung, Kecamatan Mantangai, Kabupaten Kapuas.

Kegiatan ini dilaksanakan langsung dengan melibatkan masyarakat sebagai unsur utama dalam pelaksanaan kegiatan 
kemandirian masyarakat desa (Bina Desa Mandiri Peduli Gambut), yang mana sebelumnya melalui beberapa tahapan dilakukan seleksi Fasilitator Masyarakat (FM) sebanyak 2 (dua) orang dari masing-masing desa/kelurahan yang ada dalam kawasan eks PLG sejuta hektar, persyaratan utama dalam hal ini adalah minimal lulusan SMA/SMK/sederajat dan mampu melaksanakan atau melakukan kegiatan langsung dengan masyarakat, serta berasal dari desa/kelurahan tersebut. Terkait hal ini juga masing-masing FM tersebut juga didampingi oleh pendamping sebanyak 3 (tiga) orang, yang berasal dari tenaga pendidik lingkup Fakultas Pertanian, Universitas Palangka Raya.

Tahapan dari kegiatan pendekatan pemberdayaan dimulai dengan pengorganisasian masyarakat sebagai jawaban terhadap pentingnya optimalisasi partisipasi dan efektivitas edukasi serta komunikasi kepada masyarakat melalui wadah pemberdayaan masyarakat, dimana di dalamnya terdapat usulan/program yang dibahas bersama-sama dengan masyarakat. Program kegiatan pemberdayaan masyarakat ini diwujudkan melalui penyusunan proposal Rencana Kerja Masyarakat (RKM) yang disusun oleh Tim Kerja Perlindungan dan Pengelolaan Ekosistem Gambut (TK-PPEG) yang tiap desa/kelurahan terdapat 1 (satu) TKPPEG, yang mana sebelumnya program/usulan desa/kelurahan ini tersusun dari hasil Identifikasi Masalah dan Analisis Situasi (IMAS). Untuk jelasnya dapat dilihat pada Gambar 1.

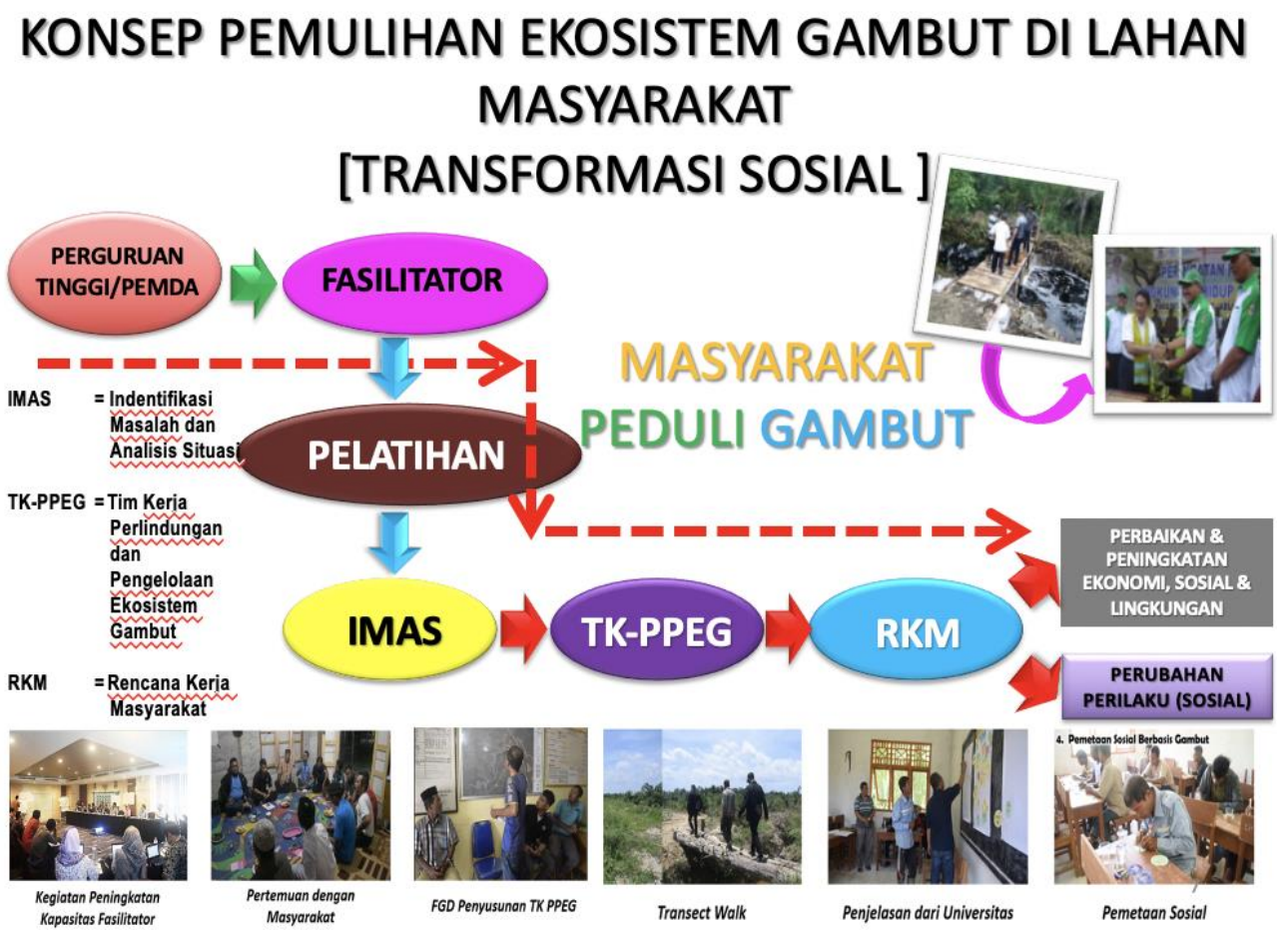

Gambar 1. Bagan Alir Konsep Pemulihan Ekosistem Gambut di Lahan Masyarakat

(Sumber: KLHK, 2020) 


\section{HASIL DAN PEMBAHASAN}

Pemberdayaan dapat diartikan sebagai upaya untuk memberikan kesempatan dan kemampuan kepada kelompok masyarakat (miskin) untuk mampu dan berani bersuara (voice) atau menyuarakan pendapat, ide, atau gagasan-gagasannya serta kemampuan dan keberanian untuk memilih (choice) sesuatu (konsep, metode, produk, tindakan, dll) yang terbaik bagi pribadi, keluarga dan masyarakatnya. Proses pemberdayaan masyarakat terkait erat dengan faktor internal dan eksternal, kedua faktor tersebut saling berkontribusi dan mempengaruhi secara sinergis dan dinamis. Pemberdayaan masyarakat memiliki keterkaitan erat dengan sustainable development dimana pemberdayaan masyarakat merupakan suatu prasyarat utama yang akan membawa masyarakat menuju keberlanjutan secara ekonomi, sosial dan ekologi yang dinamis.

Kemandirian masyarakat merupakan suatu kondisi yang dialami oleh masyarakat yang ditandai dengan kemampuan memikirkan, memutuskan serta melakukan sesuatu yang dipandang tepat demi mencapai pemecahan masalah-masalah yang dihadapi dengan mempergunakan daya kemampuan yang dimiliki. Daya kemampuan yang dimaksud adalah kemampuan kognitif, konatif, psikomotorik dan afektif serta sumber daya lainnya yang bersifat fisik/material. Kemandirian masyarakat dapat dicapai tentu memerlukan sebuah proses belajar. Masyarakat yang mengikuti proses belajar yang baik, secara bertahap akan memperoleh daya, kekuatan atau kemampuan yang bermanfaat dalam proses pengambilan keputusan secara mandiri. Berkaitan dengan hal ini, Sumodiningrat (2000) menjelaskan bahwa keberdayaan masyarakat yang ditandai adanya kemandiriannya dapat dicapai melalui proses pemberdayaan masyarakat. Keberdayaan masyarakat dapat diwujudkan melalui partisipasi aktif masyarakat yang difasilitasi dengan adanya pelaku pemberdayaan. Sasaran utama pemberdayaan masyarakat adalah mereka yang lemah dan tidak memiliki daya, kekuatan atau kemampuan mengakses sumberdaya produktif atau masyarakat terpinggirkan dalam pembangunan. Tujuan akhir dari proses pemberdayaan masyarakat adalah untuk memandirikan warga masyarakat agar dapat meningkatkan taraf hidup keluarga dan mengoptimalkan sumberdaya yang dimilikinya (Sumodiningrat, 2000). Pemberdayaan pada hakekatnya adalah upaya pemberian daya atau peningkatan keberdayaan. Pemberdayaan masyarakat dapat diartikan sebagai upaya untuk memandirikan masyarakat agar mampu berpartisipasi aktif dalam segala aspek pembangunan. Kemandirian buka berarti mampu hidup sendiri tetapi mandiri dalam pengambilan keputusan, yaitu memiliki kemampuan untuk memilih dan keberanian menolak segala bentuk bantuan dan atau kerjasama yang tidak menguntungkan. Dengan pemahaman seperti itu, pemberdayaan dapat diartikan sebagai proses terencana guna meningkatkan skala/upgrade utilitas dari obyek yang diberdayakan. Karena itu pemberdayaan masyarakat merupakan upaya untuk terus menerus meningkatkan harkat dan martabat lapisan masyarakat bawah yang tidak mampu melepaskan diri dari perangkap kemiskinan dan keterbelakangan. Perberdayaan diarahkan guna meningkatkan ekonomi masyarakat secara produktif sehingga mampu menghasilkan nilai yang tinggi dan pendapatan yang lebih besar. Upaya peningkatan kemampuan untuk menghasilkan nilai tambah tidak harus ada perbaikan akses terhadap 4 (empat) hal, yaitu: akses sumberdaya, akses terhadap teknologi, akses terhadap pasar, dan akses terhadap permintaan (Yayasan SPES, 1992). Dalam kegiatan program Bina Desa Mandiri Peduli Gambut ini lebih difokuskan pada pemberdayaan sosial-ekonomi masyarakat (dalam hal ini 
terkait PEN). Istilah pemberdayaan berasal dari kata daya yang berarti tenaga/kekuatan. Dengan demikian, pemberdayaan adalah upaya membangun daya masyarakat dengan mendorong, memotivasi, dan membangkitkan kesadaran akan potensi yang dimiliki serta berupaya untuk mengembangkannya (Mubyarto, 2000). Terkait PEN khususnya dalam program Bina Desa Mandiri Peduli Gambut adalah dengan mengimplementasikan pemberdayaan sosial - ekonomi, yang mana diartikan usaha memberi pengetahuan, keterampilan, serta menumbuhkan kepercayaan diri serta kemauan kuat dalam diri seseorang sehingga mampu membangun suatu kehidupan sosial ekonomi yang lebih baik dengan kekuatan sendiri, singkatnya pemberdayaan sosial - ekonomi bermaksud menciptakan manusia swadaya dalam kegiatan sosial - ekonomi. Pemberdayaan sosial - ekonomi pada intinya dapat diupayakan melalui berbagai kegiatan antara lain: pelatihan, pendampingan, penyuluhan, Pendidikan, dan keterlibatan organisasi demi menumbuhkan dan memperkuat motivasi hidup dan usaha, serta pengembangan pengetahuan, keterampilan hidup dan kerja (Yayasan SPES, 1992).

Adapun model pengembangan pemberdayaan masyarakat yang dilakukan dalam program Bina Desa Mandiri Peduli Gambut ini adalah model pengembangan local (locality development Model), yang diartikan sebagai upaya perubahan dalam masyarakat tingkat local, baik dalam tahap penentuan tujuan maupun pelaksanaan tindakan perubahan. Pembangunan masyarakat adalah proses yang dirancang untuk menciptakan kondisi-kondisi sosial - ekonomi yang lebih maju dan sehat bagi seluruh masyarakat melalui partisipasi aktif mereka, serta berdasarkan kepercayaan yang penuh terhadap prakarsa mereka sendiri. Oleh sebab itu paradigma pembangunan masyarakat desa adalah dengan konsep holistic, yaitu: pembangunan yang dilakukan secara menyeluruh dan terintegrasi yang sangat memperhatikan aspek spasial (pembangunan berwawasan lingkungan, pembangunan berbasis komunitas, pembangunan berkelanjutan dan pembangunan berbasis kelembagaan. Untuk mewujudkan pembangunan holistik tersebut diperlukan alternatif strategi berupa: strategi yang berorientasi pada sumberdaya atau Resource Base Strategy (RBS) yang meliputi: ketersediaan sumberdaya, factor keberhasilan, serta proses belajar. Pendekatan RBS ini adalah strategi pengelolaan sumberdaya yang berorientasi pada: kualitas, proses kerja, pengembangan, budaya, lingkungan (management by process) yang berdasarkan pada pembelajaran, kompetensi, keunggulan, berpikir sistematik, dan pengetahuan (knowledge based management).

Terkait penyusun Rencana Kerja Masyarakat (RKM) dilakukan dengan metode pendekatan yang mengkaji kondisi sosialekonomi masyarakat dengan mengadopsi MPA (Methodology of Participatory Assessment). Penggunaan RKM (Rencana Kerja Masyarakat) ini adalah untuk meningkatkan dan sekaligus memperkuat proses perencanaan partisipatif yang tanggap pada kebutuhan yang ada di wilayah desa/kelurahan yang masuk dalam kegiatan Desa Mandiri Peduli Gambut Tahun 2020. Oleh sebab itu maka, dapat jelaskan bahwa, terdapat 4 (empat) strategi pemberdayaan masyarakat yang dilakukan saat ini, yaitu: 1). The growth strategy, penerapan strategi pertumbuhan yang umumnya dimaksudkan untuk mencapai peningkatan yang cepat dalam nilai ekonomis, melalui peningkatan pendapatan perkapita penduduk, produktivitas, pertanian, permodalan, dan kesempatan kerja dibarengi dengan kemampuan konsumsi masyarakat, 2). The welfare strategy, pada dasarnya dimaksudkan untuk memperbaiki kesejahteraan. Akan tetapi, karena tidak dibarengi dengan pembangunan kultur dan budaya mandiri 
dalam diri masyarakat pada akhirnya yang terjadi adalah sikap ketergantungan masyarakat kepada pemerintah. Jadi, dalam setiap pembangunan masyarakat salah satu aspek yang harus diperhatikan adalah penanganan kultur dan budaya masyarakat, 3). The responsitive strategy, merupakan strategy yang reaktif terhadap kesejahteraan masyarakat dengan bantuan pihak luar (self need and assistance) untuk memperlancar usaha mandiri melalui pengadaan teknologi serta sumber yang sesuai dengan kebutuhan pembangunan. Satu hal yang menjadi perhatian dalam hal ini adalah kemajuan teknologi bisa tidak diimbangi dengan kesiapan sumberdaya manusia akan berakibat menjadi disfungsional, dan 4). The integrated holistic strategy, merupakan konsep kombinasi dari strategy yang diutarakan sebelumnya.

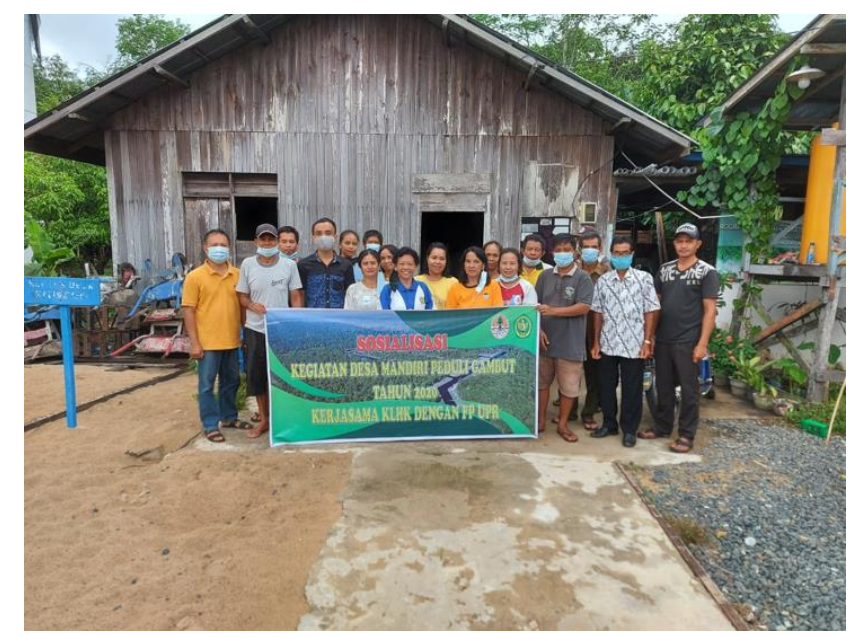

Gambar 2. Kegiatan Sosialisasi Program Desa Mandiri Peduli Gambut Tahun 2020

Kegiatan bina desa mandiri peduli gambut ini dilaksanakan sepenuhnya oleh masyrakat desa/kelurahan yang berada dalam kawasan eks PLG satu juta hektar di Kalimantan Tengah, yang dalam hal ini didukung oleh Kementerian Lingkungan Hidup dan Kehutanan bekerjasama dengan Fakultas Pertanian, Universitas Palangka Raya, yang terbagi dalam beberapa tahapan, yaitu: pra- survey lokasi kegiatan dan sosialisasi kegiatan bina desa mandiri peduli gambut, rekruitmen dan seleksi FM, penyusunan dokumen IMAS, pembentukan TK-PPEG, pelatihan FM dan TK-PPEG, penyusunan RKM, dan pelaksanaan kegiatan program yang telah disusun sebelumnya dalam RKM, serta evaluasi kegiatan di lapangan. Untuk jelasnya dapat dilihat pada Gambar 2, 3, dan 4. 


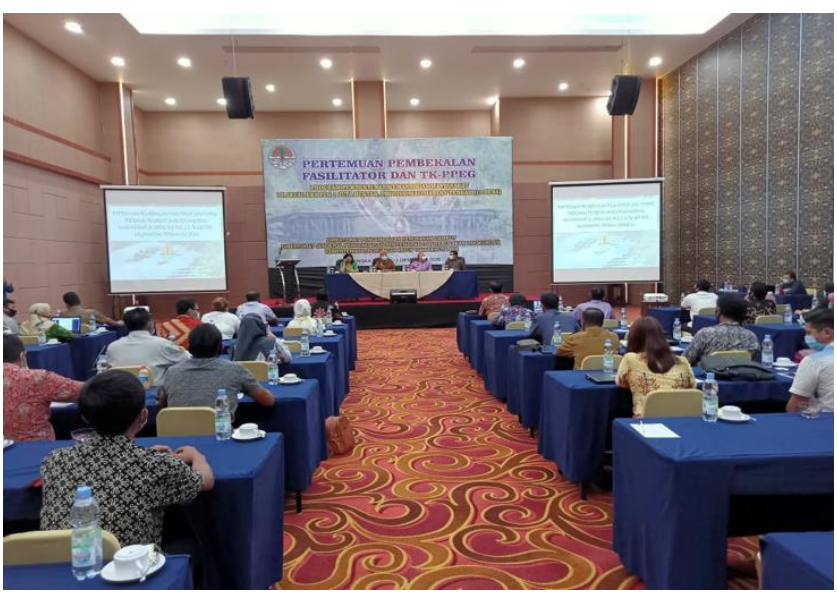

Gambar 3. Kegiatan Pelatihan dan Pembekalan Fasilitator Masyarakat (FM) dan TK-PPEG

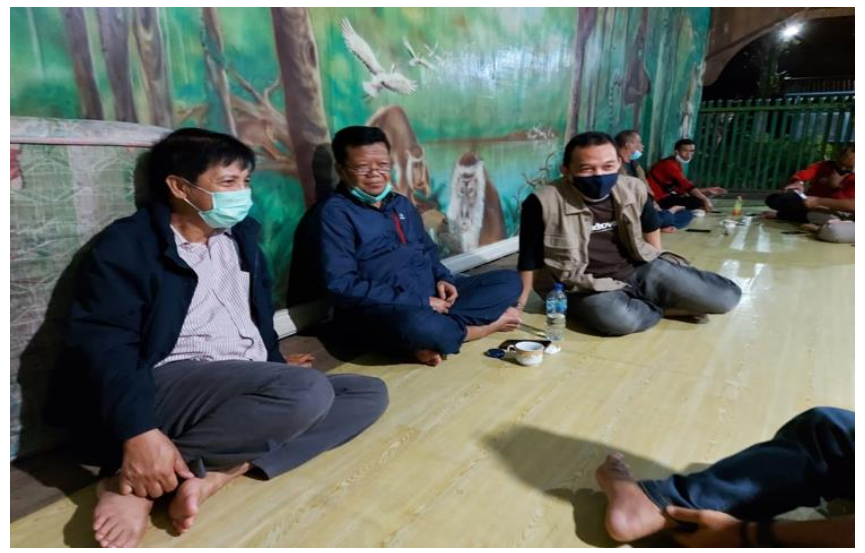

Gambar 4. Arahan KLHK dengan Tim Pendamping FM

Adapun jumlah masyarakat yang terlibat dalam kegiatan bina desa mandiri peduli gambut tahun 2020 ini dalam hal ini melalui program kegiatan desa atau rencana kerja masyarakat (RKM), yang juga merupakan bagian dari program PEN, yaitu: Desa Babai sebanyak 100 orang), Desa Tumbang Muroi sebanyak 100 orang), Desa Tampulang sebanyak 296 orang, Desa Tanjung Sangalang sebanyak 60 orang, Kelurahan Panamas sebanyak 106 orang, Desa Tabatan sebanyak 31 orang, Desa Lahei Mangkutup sebanyak 127 orang, Desa Penda Barania sebanyak 83 orang, Desa Mantangai Tengah sebanyak 90 orang, Desa Katimpun sebanyak 112 orang, Desa
Mantangai Hilr sebanyak 120 orang, Desa Mantangai Hulu sebanyak 170 orang, Desa Sei Ahas sebanyak 121 orang, Desa Sei Jaya sebanyak 170 orang, Desa Katunjung sebanyak 63 orang, Desa Kalumpang sebanyak 150 oarng, Desa Mahajandau sebanyak 39 orang, dan Desa Pulau Kaladan sebanyak 85 orang, total keseluruhan masyarakat yang terlibat sebanyak 2.023 orang masyarakat.

Sedangkan RKM yang dilaksanakan dengan melibatkan masyarakat, meliputi: revegetasi, perikanan, peternakan, pertanian, dan lainnya, yang tentu saja terkait dengan 3R (Rewetting, Revegetation, and Revitalization). Dengan melaksakan kegiatan ini akan 
berdampak terhadap masyarakat sekitar kawasan gambut tersebut.

\section{KESIMPULAN DAN SARAN}

Adapun kesimpulan dari kegiatan Bina Desa Mandiri Peduli Gambut yang dilakukan di Provinsi Kalimantan Tengah, adalah:

1. Model pengembangan pemberdayaan masyarakat yang dilakukan dalam program Bina Desa Mandiri Peduli Gambut ini adalah model pengembangan local (locality development Model), yang diartikan sebagai upaya perubahan dalam masyarakat tingkat local, baik dalam tahap penentuan tujuan maupun pelaksanaan tindakan perubahan.

2. Kegiatan bina desa mandiri peduli gambut ini dilaksanakan sepenuhnya oleh masyrakat desa/kelurahan yang berada dalam kawasan eks PLG satu juta hektar di Kalimantan Tengah, yang dalam hal ini didukung oleh Kementerian Lingkungan Hidup dan Kehutanan bekerjasama dengan Fakultas Pertanian, Universitas Palangka Raya, yang terbagi dalam beberapa tahapan, yaitu: pra-survey lokasi kegiatan dan sosialisasi kegiatan bina desa mandiri peduli gambut, rekruitmen dan seleksi FM, penyusunan dokumen IMAS, pembentukan TK-PPEG, pelatihan FM dan TK-PPEG, penyusunan RKM, dan pelaksanaan kegiatan program yang telah disusun sebelumnya dalam RKM, serta evaluasi kegiatan di lapangan.

3. Melalui kegiatan ini pelaksanaan edukasi secara langsung dengan masyarakat melalui kegiatan perencanaan, pelaksanaan, pengawasan kegiatan terkait 3R, yang tentu saja kedepannya akan tercapai kemandirian dari masyarakat, melalui program PEN ini.

\section{DAFTAR PUSTAKA}

https://www.worldometers.info/coronavirus/?u tm_campaign=homeAdvegas 1 ?

Kementerian Keuangan Republik Indonesia. 2020. Program PEN (Pemulihan Ekonomi Nasional). https://www.kemenkeu.go.id/media/153 65/photostory_pen.pdf

Mubyarto, M. 2004. Menuju Sistem Ekonomi Pancasila: Reformasi Atau Revolusi. Journal of Indonesian Economy and Business, 19 (1).

Sumodiningrat, G. 2000. Visi dan Misi Pembangunan Pertanian Berbasis Pemberdayaan. Yogyakarta: IDEA.

Yayasan, S. P. E. S. 1992. Pengembangan Berkelanjutan. PT. Pustaka Utama. Jakarta. 